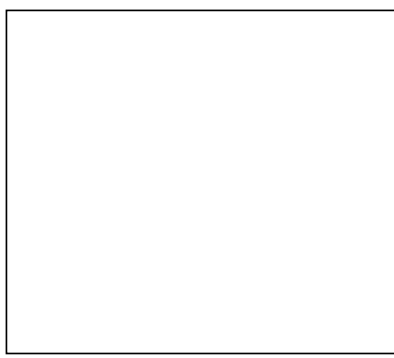

\title{
To live in the city centre: housing and tenants in central neighbourhoods of Latin American cities
}

\section{Hans Harms}

SUMMARY: After reviewing structural changes in metropolitan areas of Latin America and the implications for housing, this paper describes five central neighbourhoods with a predominance of rental housing: three in Lima and one each in Havana and Rio de Janeiro. This includes the types of buildings, how, when and why they were built, who occupies them and who owns them. It also describes what influence government policy has had on them and what measures (if any) have been taken to maintain or improve them by owners and tenants. In some of the case study areas, it is the tenants, not the owners, who are committed to their neighbourhood and who are taking on most of the responsibility for their neighbourhood.

Hans Harms teaches at the Technical University in Hamburg and part time at the Development Planning Unit, University College London. He has worked for many years on housing and urban renewal in Latin America and has published widely on housing and self-help in Germany as well as in the South. His most recent book is Vivir en el "centro" edited with W. Ludeña and $P$. Pfeiffer (see note 1 for further details) and this paper is based on this book's concluding chapter.

Address: 29 South Hill Park, London NW3 2ST, UK; fax (44) 1714353953.

1. Harms, H., W. Ludeña and $P$. Pfeiffer (editors) (1996), Vivir en el "centro"; Vivienda e Inquilinato en los Barrios Céntricos de las Metrópolis de América Latina,

\section{INTRODUCTION}

THIS PAPER PRESENTS the findings of a research project coordinated by Technische Universität Hamburg-Harburg whose core focus is the study of three central rental neighbourhoods in the city of Lima, Peru and of one neighbourhood in each of Río de Janeiro, Brazil and Havana, Cuba. The research sought to analyze the cause and effect relationship that exists within the processes which create and convert central rental neighbourhoods, also to identify existing problems, and to compare conflicting factors that are determinant at the international level. The full findings of the research are published in Spanish. ${ }^{(1)}$ The paper also refers to developments in other Latin American cities, to provide an additional basis for comparative interpretation.

The paper discusses and analyzes the following themes:

- structural changes in Latin American metropolitan areas in the international context;

- the development of central-city rental housing areas and the types of building involved;

- current dynamics of the real estate and rental housing markets - owners, tenants and other actors; and 
280 pages. Published by and available from Technische Universität Hamburg-Harburg, Arbeitsbereich 1-07: Städtebau III, Objektbezogene Stadtplanung, Woellmerstr. 1, 21075 Hamburg, Germany; price 25 marks (for post and packing add 25 per cent for orders from Europe, 40 per cent for orders from elsewhere). Payment by Eurocheque or International Money Order made out to Hans Harms. More details of the book are given in Book Notes.
- conflicting interests in central rental neighbourhoods and possible future perspectives for these neighbourhoods and residents.

\section{STRUCTURAL CHANGES AT THE METROPOLITAN LEVEL IN THE INTERNATIONAL CONTEXT}

THE RAPID DEMOGRAPHIC growth that began in the 1950s has caused a vast increase in the surface areas of many cities. Urban development, generally uncontrolled, has consumed large areas towards city peripheries while central neighbourhoods have fallen into neglect.

From the 1960s until the early 1980s, this development followed a domestic migration model in which the population moved from city centres to the peripheries. This phenomenon was identified by John Turner in the 1960s to explain the development of squatter communities, or barriadas, in Lima, on the basis that recent arrivals from the provinces first migrated to the city centre, possibly where they had family members or acquaintances, or as tenants in areas close to possible sources of employment. After a period of adaptation of several years in the central rental neighbourhoods, the migrants would establish a family. The desire and need for larger and lower-cost living space and the fact that families could not find adequate, affordable housing on the private market or within government housing programmes led to movement from the cramped, overpopulated rental neighbourhoods located in the city centres towards the peripheries and the self-constructed settlements or barrios autoconstruidos. This movement might also reflect the desire to have access to land and house ownership with a view to acquiring security and the right of permanence, the possibility of beginning with a shanty and, over time, obtaining a more adequate house.

In the next step, house and family were consolidated in squatter settlements, barriadas or favelas which were established by groups of residents on the periphery. For this to occur, there has to be potential for employment and thereby for securing an income for the family. The emerging urban structure produced an horizontal expansion of constructed areas with a relatively low occupation density. The city centre and existing rental housing received little attention in this intra-urban migration model.

In the mid-1980s, in many large cities, this urban development model based on the expansion of the surface area reached its limit. The increasing distances between dwellings on the periphery and workplaces, most of which were located in or near the centre, meant greater household expenditure in terms of time and transport. In addition, it was becoming increasingly difficult or impossible for the new generation of residents to obtain land in peripheral areas, at a low cost or free of charge, that could be developed for housing . State and municipal institutions also faced problems such as increases in public costs for extending the infrastructure to the peripheral areas while 
the existing infrastructure in the city centre was underutilized and buildings were deteriorating.

A new trend emerged at the metropolitan level in many Latin American cities, for example in São Paulo and to some extent in Lima. Population growth rates in peripheral areas were on the decline while population numbers were increasing in central districts. This new trend cast doubt on the dominant urban growth model prevalent until the 1980s which was based on extensive development of the cities.

Current structural transformations in the cities show increased building densities (multi-level constructions, sub-divided houses and extension of buildings into public and private open spaces). These increased densities are found in central neighbourhoods and their vicinities, including moderate and low-income rental neighbourhoods, as well as in older and better established spontaneous settlements near the centre. This trend towards higher densities may have both positive and negative repercussions on the living conditions of the residents, the supply of housing for low-income groups and the development of the neighbourhoods.

If the intention is to reduce adverse consequences and strengthen positive ones, then a new vision or model for higher density cities must be established. This model would have to take into account both social and environmental factors (sustainable, appropriate and forward-looking development). Proper development of this new and higher density city would require open discussion between the various actors in the city with a view to formulating schemes that, together with technical and legal factors related to the increasing density of existing neighbourhoods, would also provide for discussions on effective planning and decision-making mechanisms among the parties involved (owners, residents, various urban and state institutions, and other special interests). Rather than focusing on the "architecture" or rehabilitation of historic centres, it would have to target processes that take due account of technical and construction factors as well as social, economic and political matters. The most important factor for the residents is to remain in the centre, close to job opportunities.

The intensity of the densification trends varies in the cities

2. Densification needs to be more clearly defined, i.e.: building density (built-up area per plot or urban area); population density (number of persons per hectare or area); occupancy rate (number of persons per room, dwelling or house). studied. ${ }^{(2)}$ For a better understanding of the different forms of urban growth and the different degrees of densification, a number of factors need to be examined, namely:

- opportunities for access to urbanizable land;

- difficult topography;

- global city effect, i.e., linkage of metropoli with the global economic structure and global capital flows;

- urban and national modernization projects;

- changes in the centre-periphery relationship.

\section{a. Opportunities for Access to Urbanizable Land}

In cities where, for various reasons, access to urbanizable land is (or was) relatively easy, the expansion of urban areas will be 
3. These figures cover the whole metropolitan area. They do not indicate that in low-income areas, population densities are higher and in high-income suburbs they are lower. greater but with a concomitant lower level of planning during the urbanization process. This is true for the city of Lima, for example, where, between 1969 and 1985, the population increased 2.5-fold and the urbanized surface area 3.5-fold. ${ }^{(3)}$ Lima, and its surrounding agricultural areas, is an oasis irrigated by the Rimac river, situated in a barren area on the coastal plain. Wastelands located beyond the range of the irrigation systems, and unsuitable for agricultural purposes, were generally owned by the state and were of virtually no significance to the urban or agricultural land markets. This is the area of the urban periphery that was invaded, beginning in the 1950s, and where the construction of squatter communities took place.

Meanwhile, two types of land market emerged: the formal market which included agricultural areas suitable for irrigation and the "legally urbanized" city (this land was generally privately owned); and the informal market composed of barren land originally owned by the state and which came to include the squatter communities, some of which were later legalized. These markets became partially superimposed and the separation between them is now less clear than in the past.

In other Latin American cities, such as Buenos Aires and Montevideo which are located on agricultural land not requiring irrigation systems, there was also unbridled expansion of surface areas. Access to land for the construction of (partially illegal) houses and settlements was not free of charge as in Lima. The land was privately owned and had to be bought by the settlers. However, agricultural land was sold illegally as unserviced, urbanizable land.

\section{b. Difficult Topography}

In Río de Janeiro and Caracas, the topography is characterized by mountains and fairly narrow valleys. It follows that urbanizable land in or near the centres is scarce and valuable. Squatter settlements, favelas and ranchos were diverted to sloped areas which can be quite steep.

The process of urbanization in these areas is more difficult than in flatter areas and technical problems emerge in the construction of connecting roads and infrastructure networks as do geological problems, for example, the danger of house collapse in steep urbanized areas. Spontaneous settlements take on a different urban form in this mountainous topography: regular land sub-division and orthogonal street plans used in flat areas are replaced with a layout of blocks and lots adapted to the local topography and contour lines.

In Caracas and Río, connections between different parts of the city are sometimes only possible with the construction of tunnels. In these cities, there is a high concentration of office buildings and high-rise housing for the middle and upper social classes. In Caracas, these concentrations are found in a broad valley, whilst in Río de Janeiro they are found along the Atlantic shorelines and beaches. In the inner-city, the scarcity of urbanizable land created intense pressure for redevelopment and higher exploitation of the land. Accordingly, only some parts 
of the historic old city and urban residential neighbourhoods near them were preserved.

\section{c. The Global City Effect}

In Río, as in Caracas and Panama City, the global city effect plays an important role. In other cities, such as Havana and Lima, there are few effects of globalization. Within the framework of the formation of transnational markets and regional economic agreements (for example, the foundation of Mercosur in the southern cone of Latin America), the cities of Montevideo on the Atlantic side and Santiago on the Pacific side aim to establish themselves as regional financial and service centres. They also aim to strengthen their role as hubs for global transportation networks and maritime ports, and to provide further connections to São Paulo and Río in southern Brazil. In areas where transnational corporations and international financial institutions have a solid operating base, or in areas where they wish to expand, there is a great demand for office space in the city centres. This results in increasing land values in selected areas (primarily in the central business districts) and growing speculative expectations among landowners. This situation may also put pressure on the real estate markets in terms of land redevelopment for higher yields, potentially leading to an intensified expulsion of residents and the disappearance of residential property use.

Panama is in a privileged position due to its location between North and South America, and between Asia and Europe. Since the 1960s and 1970s, it has been transformed into a regional financial centre where both legal and illegal financial markets have developed. This situation, combined with US supremacy in Panama since the construction of the Panama Canal, has had very important repercussions on the creation and development of central rental neighbourhoods. The situation is quite different in Panama than in other Latin American countries.

\section{d. Urban and National Modernization Projects}

Redevelopment and demolition programmes already existed in Río de Janeiro at the turn of the century and later. During the 1930s and 1950s, such programmes had the stated objective of building a new and modern city. To that end, hills (including Moro de Castello with the original fort) that accentuated the historic urban image of the founding era were destroyed, levelled and filled into the sea to create additional land. Furthermore, mansions and workers' housing areas located in the city centre were demolished to make way for the characteristic wide avenues and new, larger plots, opening the way for modern urban development with high-rise buildings. This formed the basis of the new central business district shaped along the lines of the US city model characterized by skyscrapers in the 1920s and 1930s.

The urban development process was different in Lima. Modernization began with the demolition of the city walls and the 
opening up of the colonial city. It continued with the Plan de las Grandes Avenidas, or great avenues plan, whereby the agricultural areas between the old city and the sea were urbanized. This connected the historic urban nucleus with the seaside resorts, making new residential areas available for the villas of the middle and upper-classes. During the 1960s and 1970s, the centre of tertiary activities shifted south-west from the historic centre to Miraflores and San Isidro.

Although transformations and modernization were planned for the historic centre of the city, very little was actually carried out. Migration of the middle and upper social classes from the historic centre to the south and west began during the early decades of the twentieth century. This process was accelerated and consolidated by the severe earthquake of 1940. The lowerincome sectors remained in the centre, in areas abandoned by the middle and upper-classes, and in the workers' neighbourhoods that emerged at the beginning of the century (and some before then) located to the north and east of what, at the time, was the periphery of the city (Rimac, La Victoria, and El Agostino).

The modernization process consolidated social and spatial segregation within the metropolitan area. It was reinforced by migration from the provinces and by the urban sprawl of the informally built barriadas and the formally planned urbanizaciones (the settlement areas of upper and middle-class groups) both of which essentially began during the 1940s and 1950s.

The composition of the in-migrant or immigrant population varied within each city studied. In Lima, as in other Andean metropoli, the population was of indigenous origin. In the southern cone, i.e., Santiago, Buenos Aires, Montevideo and São Paulo, most of the immigrants were of European origin. In a later phase, especially in Brazil, in-migration from the poor north-eastern provinces increased.

\section{e. Changes in the Centre-Periphery Relationship}

When cities grow, the area known as the periphery becomes increasingly distant from the centre. As time passes, and with each expansion, new peripheries emerge which develop their own sub-centres as a result of their remoteness from the main centre. In most cases, the hub of economic activity no longer coincides with the original historic centre. In Rio, the historic centre maintained its central function as a result of a series of demolitions and early urban redevelopments. Newer buildings and another urban layout had replaced the largest part of the old colonial city. It followed the emergence of wealthy seaside settlements in the southern coastal areas in the 1920s and 1930s such as Copacabana, later followed by Ipanema and finally, in the 1980s, by Tujicamar. In the old centre, there is still excess land in the form of empty lots, due to the early demolition of buildings. These areas have remained vacant for decades and, today, they are wastelands. Overvalued on the real estate market, they are not accessible for residential use by the majority of the population. In fact, housing was legally excluded from this area - although this has been changed recently. 
The old centre of Lima underwent a different transformation. There has been an increase in population and in economic activity but these are different from what existed 30 years ago. The Andean population has taken possession of the centre, bringing to it their way of life and significantly changing the economic and symbolic significance of the area which had been neglected and abandoned decades previously by the middle and upper-classes. Since 1996, after the completion of the research, a new phase has been initiated. Informal street vendors are banned from the historic centre. The national and metropolitan governments are in competition to "reorder" and reconquer the centre for new capital investments.

The dynamics are different in Santiago and Montevideo. The workers' rental neighbourhoods in the vicinity of the old historic centre deteriorated and lost their original significance. In these areas, no densification occurred except in a few neighbourhoods. By contrast, census data indicate a general decline in population in Montevideo's centre. Over the past 20 years, the population in the historic city centre has decreased by approximately 40 per cent. Three central urban districts - Ciudad Vieja, Palermo and Barrio Sur - have lost 10,000 inhabitants in absolute terms. What has happened to the centre? The "heart of the city", the commercial and symbolic centre, has moved with the cultural, commercial and residential activities of the middle and upper social classes to Montevideo's attractive eastern coast. The lower social strata moved to the western coast and to the access roads north of the city. Estimates by the Frente de Inquilinos, the metropolitan tenants' association, show a sharp increase in the number of people evicted from the centre, with an unprecedented high since the early 1990s, with more than 10,000 residents per year moving out of the area. Some people moved to the periphery of the city, through illegal occupations or land purchases. Another phenomenon also occurred: many empty houses, hotels and factories located in the central areas were illegally occupied by the homeless.

What caused this trend? The rent freeze, in effect since 1974, led to increased deterioration in buildings as owners did not invest in maintenance. When this legislation was repealed, with the subsequent fast and steep rise in rents, an increasing number of tenants were evicted and dispossessed. Run-down housing was officially declared as unfit for habitation and closed down. Merely one month's arrears in rental payments could constitute valid grounds for terminating a contract and turning the tenant onto the street.

Beginning in 1973, Santiago also underwent an intense urban territorial expansion against a backdrop of relatively low levels of population growth. It follows that the average population density declined in respect of the city's total area. Intense territorial expansion is viewed as the direct result of the implementation of neo-liberal economic principles. The removal of boundaries between urban and rural land made an unlimited amount of urbanizable land available on the urban land market, leading to a rapid growth in surface area. The burgeoning city consumed the best farmland. At the same time, there was 
an increase in traffic and the number of cars and lorries, exacerbating the already critical environmental situation.

Part of Santiago's central district was transformed into an exclusive central business district (CBD) after the fashion of development in North American cities. The price of land per square metre reached its highest value in this area. In this process, residential uses were excluded from the central business district. During boom periods, real estate market expectations for commercial and tertiary land use expand, leading to the replacement of residential use in the surrounding areas with more lucrative commercial purposes. This occurred, however, only along an eastern axis, towards the luxurious, leafy residential areas of the upper-classes. In other areas near the central business district, to the west and south, the old land uses remained the same. This area consists of run-down, poorer residential areas and the price of lots is still relatively low.

People living in the centre wished to remain there. During the military dictatorship, the lower-income sectors were evicted in connection with special "eradication" programmes. The openly stated political objective was to create "homogeneous socio-economic areas in the city". Between 1979 and 1985, 2,000 families were evicted under such programmes. A climate of isolation and fear was created with the disbanding of all neighbourhood organizations under the 20 years of Pinochet's military dictatorship. The experience of having lost all control of their own living conditions weakened the organizing strength and will of the lower-income groups. Even today, there is little organized resistance to the process of expulsion. For Chile's upper-classes, the exemplary model of urban development in recent years has been characterized by US influence. Extensive garden suburbs with large shopping malls situated beside wide highways travelled by unrestricted automobile traffic are viewed as a modern ideal.

\section{f. Conclusions}

To conclude on the subject of structural change in the cities studied, our assessment is that increasing densification is taking place in the inner-city areas of Lima, Caracas, Río de Janeiro, Havana, and São Paulo. In Montevideo and Santiago, expansion is taking place towards the periphery, while the population is declining in the central areas. These trends, especially in Santiago, can be explained by the authorities' explicit refusal to use urban planning and urban growth management in the city. In both Santiago and Montevideo, the freeing of the urban land markets from planning regulations and the liberalization of rental laws benefitted the property owners. These two policies foster a form of urban development that directly contradicts the objectives of promoting a sustainable development which takes into account social factors and which respects the environment. Rather than complete liberalization of land and rental housing markets, urban intervention and management are required through policies that take due account of the people they affect. 


\section{THE DEVELOPMENT OF CENTRAL-CITY RENTAL HOUSING AREAS AND THE TYPES OF BUILDING INVOLVED}

\section{a. Development of the Housing Areas}

THE CENTRAL HOUSING areas in the cities studied were formed largely during the last century. These areas have undergone a number of developmental phases. In the beginning, they were located on the outskirts of the historic centre, that is, on the periphery of each of the cities.

The neighbourhoods created at that time were, in their configurations in terms of space and construction, closely related to the morphology of the existing city. New types of buildings correlated directly with the economic and social processes of the city's expansion at the time, and with owners' activities and attitudes as they sought to optimize their properties and the use of their buildings. While there are a number of different direct reasons for the creation of these urban areas, there are the following common factors: nascent industrialization processes, the construction of railroads, the emergence of a working-class with an increasing demand for low-cost rental housing and a growing process of migration to the cities. In general, this was when capitalist production began in Latin America. In addition, investment in rental housing construction seems to have been one of the few secure forms of capital investment for the newly-emerging small and medium middle-class.

Areas in the three cities of Lima, Rio and Havana (where the research was focused) were selected to represent typical urban housing areas in each city, having building types and leasing arrangements that are relevant today.

\section{i. Lima}

Two areas chosen in Lima are directly connected with the historic centre. The third area is located in Lima's first urban expansion zone, La Victoria. The three cases represent distinct types of workers' housing.

Monserrate - This neighbourhood is composed of 19 regular housing blocks connected directly to the western limit of the original old city. It is located just five blocks from the Plaza de Armas and the president's palace. The ownership structure in the area was determined by the major land owners (the Church, the university and the convents). During the nineteenth century, the residential area was transformed into a multiple-use area with the construction of the railroad and the numerous workshops that accompanied it, and the middle-class residents abandoned the area. Little attention was paid to building structure which, to this day, presents varying degrees of neglect and overcrowding. The area selected for the case study includes six housing blocks with a total of 1,272 dwellings and 5,329 residents. It covers an approximate surface area of ten hectares, with a gross density of 527 residents per hectare. Interviews were conducted in 77 dwellings, including 333 residents. 
Barrios Altos - This is a large neighbourhood bordering on the east side of the old city and extending to the area where the former reducción de los indio (or Indian village created by the Spanish during the colonial period) was located. Street patterns and lot sub-division are irregular. In colonial times, the area was made up of large gardens with houses and convents, and irrigation ditches from the pre-Hispanic period. Between the eighteenth and nineteenth centuries, artisanal workshops, a gunpowder plant, a prison and a hospital were established. Despite all this development, the neighbourhood did not lose its residential character. The area studied is composed of three blocks of different sizes, with 1,318 dwellings and 6,274 residents. It covers a surface area of approximately 11 hectares, with a gross density of 550 residents per hectare. Interviews were conducted in 104 dwellings, including approximately 500 residents.

Mendoza Merino - In contrast with the two preceding areas, this neighbourhood is located in the district of La Victoria, on the periphery of the historic city. Beginning in 1940, a series of construction projects of city-wide importance were undertaken here, for example, Mercado La Parade, Alianza de Lima sports stadium and the construction of a major, high-density housing project for low-income families. Known as El Porvenir, and financed by the private sector, this project included 16 blocks with a gross density of 8,000 residents per hectare. La Victoria was consolidated as a mixed-use area with residential and industrial functions. Beginning in 1950, large numbers of people migrated here from the provinces. According to the $1981 \mathrm{popu}-$ lation census, there were 56,361 dwellings in the district of La Victoria, including some 88 per cent collective housing, with the area exhibiting distinct characteristics of inner-city slums (tugurios). The case study includes six blocks of different sizes, occupying a surface area of approximately eight hectares. It includes 609 dwellings with a gross density of 408 resident per hectare. Interviews were conducted in 103 dwellings, including 563 residents. The sector, in terms of streets and building structure, is a superimposition of two different urban morphology systems. Land originally occupied by agricultural activities became part of Hacienda Mendoza. Another area, Jardines Mendocita, maintained its original garden use until, in 1932, it was sub-divided into long, narrow plots initially used as garden plots and later transformed into alleys aligned on a central street (now known as Avenida Diagonal Mendoza). This urbanization was transformed beginning in the $1940 \mathrm{~s}$, adopting a regular street pattern which, as early as 1870, had been planned for the location of the La Victoria neighbourhood.

\section{ii. Rio de Janeiro}

The area studied in Río de Janeiro is located in Barrio Lapa, part of the central administrative district between the old heart of the city (now the financial and commercial centre) and the northern urban areas. It is located amid a concentration of commercial, industrial and service enterprises. In addition, the sur- 
rounding areas include public institutions and new cultural facilities. There is intensive vehicle and pedestrian traffic at all hours of the day and the area includes a wide variety of rental dwellings.

\section{iii. Havana}

In Havana, Barrio Atares was selected. This is an old workers' neighbourhood located near the port, railway freight lines and a market. It has always been a poor settlement, holding no attractions for the moderate and upper-income sectors. The first building appeared during the eighteenth century after the liquidation of a hacienda. The urbanization is very dense with buildings one to two storeys high.

\section{b. Emergence of New Housing Types Historically linked with Urban Development Phases}

The emergence of new building types in the areas studied is interpreted in the context of a close historical linkage with different phases of investment in housing observed in the course of the expansion of the cities.

The first phase which is significant for our purposes began during the mid-nineteenth century. The cities were composed of an historic centre with a varied mix of land uses (housing, artisanal production and trade) and the first urban expansions (arrabales and barrios de extramuros).The land-owning upperclasses lived in Lima and Havana (cities of Hispanic origin), in large casonas, or historic court-houses, with gardens, built on traditional lots measuring approximately $110 \times 110$ metres. The lower-classes or dependent sectors of society (freed slaves, domestic servants, etc.) lived either in the same houses as the upper middle-classes, within the courtyards of these houses, or in special building types such as the callejones found in Lima.

There was accelerated economic growth in Peru during this time largely as a result of the exploitation and export of guano deposits. ${ }^{(4)}$ Increasing incomes in both the private and state sectors were invested largely in the city of Lima, leading to an initial cycle of urban area expansion. Along with the construction of roads and railways to the port of Callao and the seaside resorts, an industrialization phase developed, predominantly in the textile and food-processing sectors. For the first time, some of the private sector revenue was channelled into speculative investment with the construction of simple rental houses for workers. These constructions often took on the form of casas de vecindad or solares.

In Havana, a different process occurred. Due to the wars of independence and the loss of the colonies, many Spaniards from the lost provinces of South America came to Havana, the only major capital of the diminished Spanish empire. Havana became the capital of the coffee and sugar cane plantation region, supported primarily by the work of slaves. The urban population became more heterogeneous and new housing was needed to accommodate workers and immigrants (freed slaves and impoverished Spaniards). Railways and ports were built. At the 
same time, investments in new types of buildings, known as cuarterias and cuidadelas, were made. These buildings, two to three stories high, had internal access through communal balconies and were equipped with communal facilities (toilets and drinking water).

Other housing types and building blocks developed in Río de Janeiro. The Portuguese colonial city related more to the local topography and the coastline, hills and location of nearby marshes gave Río an irregular urban configuration. Moreover, no ordinances existed for building a symbolic central plaza to accommodate government buildings, as occurred during the Spanish foundation of the cities governed by the Leyes de Indias. In Rio, houses were built on long, narrow lots with rear gardens connected in turn to winding streets. The hub of urban activity was in the centre and at the port. At the time, warehouses, factories, administrative buildings and commercial structures were erected. Workers and the poor (freed slaves and immigrants from Europe and from the Brazilian provinces) also concentrated in these areas. Some of the one and three-storey colonial buildings were replaced with structures known as cortiços and casas de comodos.

Urban landowners and small-scale investors (nouveau riche investors from the commercial and artisanal sectors) began to increase building densities in the city. In all the cities studied, similar forms of collective housing appeared but were given different names depending on where they developed. In Río and São Paulo, they were known as cortiços; in Lima, casas de vecindad or solares; in Havana, cuarterías or ciudadelas and, in Santiago and Montevideo, conventillos.

At the turn of the century, approximately 20 per cent of Rio's population lived in cortiços. In Lima and the other cities, overcrowding became worse within these blocks and buildings. Outbreaks of yellow fever and cholera epidemics accompanied this densification due to the dearth of sanitary conditions.

In many Latin American capitals at the beginning of the twentieth century, there was public discussion of the problems of overcrowding and insalubrious conditions in the houses and blocks occupied by the lowest classes of society. It was believed that the existence of these "slums" was a hazard to public health and to the upper-classes and they were directly blamed for the periodic outbreak of epidemics. Doctors and engineers demanded that either hygienic conditions in the cortiços, casas de vecindad and callejone be improved or that these "slums" simply be destroyed. New hygienic standards were proposed although, in many cases, they did not solve the problem.

With the fight against this type of collective housing began a second phase of real estate development involving cooperation between various actors. The state undertook a number of initiatives beginning in 1910, in Rio de Janeiro, with the prohibition of the construction of new cortiços and a definition of new hygienic standards for construction. With the first urban renewal programme (1902-1906), countless cortiços in the city were destroyed. At that time, more than 2,500 dwellings, single-family and collective, were destroyed. During this process, approxi- 
5. Vaz, Lilian Fessler (1985), Contribuição ao Estudo da Produção e da Transformação da Habitação Popular - as Habitações Coletivas do Rio Antigo, UFRJ/IPPUR, University of Río de Janeiro, MSc thesis.
6. de Quieros Ribiero, Luiz Cesar (1993), "The formation of development capital: a historical overview of housing in Rio de Janeiro", International Journal of Urban and Regional Research Vol.17, No.4, pages 547-558. mately 36,000 residents were evicted from their homes. In addition to the state, small-scale entrepreneurs from the nascent real estate sector entered the scene, introducing new types of buildings and new forms of urbanization. ${ }^{(5)}$ Thus began a new phase in the production of rental housing in the city of Rio.

Until 1925, and pending the new regulations, avenidas were constructed; these were simply small row houses facing private streets with obligatory spaces designed especially for toilet and kitchen. Middle-class investors and construction entrepreneurs found avenidas to be an attractive form of investment, yielding rapid returns and secure long-term income. However, this type of housing was beyond the means of the poor from the cortiços as it required the stable and somewhat higher incomes found among the middle to lower-class specialized workers. In 1925, factory owners began to build vilas operarias for the workers, and other investors constructed vilas which were somewhat more spacious row housing only affordable to the middle-class.

The public discussion on hygiene also produced some results in Havana and Lima. In the latter city, a similar form of housing, quintas, appeared. This particular form of row housing, located in the interior of the block, was generally built on two floors around a semi-private central courtyard used to access single-family dwellings. Each unit was connected to the drinking water and sewer systems. In Havana, a number of quintas de salud and pasajes were constructed while in Santiago, they were known as cites.

The last type of construction to be presented in this study appeared during the 1920s and 1930s - the modern edificios de departamentos or apartment buildings. This was the beginning of a third phase of investment, most evident in Río de Janeiro where, with the modernization efforts of the state, new large real estate enterprises, appeared on the urban scene. Their activities culminated in the construction of Copacabana. The process of social and spatial segregation accelerated at the same time. The construction of these luxury high-rise dwellings for a new middle-class demanded much larger volumes of capital investment and different sources of financing than did the lower middle-class and smaller-scale housing that had been built until then, that is, cortiços and vilas. Investment in the latter types of housing to all intents and purposes came to an end.

In 1935, the building of callejones with adobe was prohibited in Lima. With the advent of construction techniques using concrete slabs and pillars, high-density rental housing up to six storeys high was built in the city without the benefit of lighting or ventilation standards. The example of the El Porvenir buildings in the district of La Victoria was criticized as being callejones verticales, vertical modern slums.

The increasing inflow of finance capital into real estate development led to a gentrification of the housing market. ${ }^{(6)}$ In other words, access to the formal housing markets, governed by standards of hygiene, gradually became possible only for the middle and upper-classes. This process marginalized a large sector of the population, excluding them from the market as they were forced to seek other solutions. Some found the only affordable 
7. The percentage distributions of the types of buildings present in the three areas studied in Lima are included in the original study listed in reference 1 : see pages 40-49 and Table 8; see also pages 115-117 for details of the present types of buildings and their qualitative distribution in Havana's Barrio Atares and pages 155-158 for Río de Janeiro's Barrio Lapa.
8. The functions and characteristics of each are clarified and described for the first time in the chapter on Lima by Luis Chirinos in Harms, Ludeña and Pfeiffer (editors) 1996, see reference 1. solution in favelas, through self-building of a living space, while others resorted to the rental markets in city centres. Thus, inflows of finance capital into house-building and real estate production, together with high standards, brought about sharply conflicting effects: while they excluded low-income groups from the market, they necessitated the construction of favelas and barriadas through the practice of self-help activities.

The present stock of housing in the case study areas of the three cities is composed of building types originating from the various historic phases studied. While different terms are used depending on which city is involved, certain common factors and elements can be identified in the form of construction and building types as well as in the functionality of the dwellings. A process of deterioration occurred as a result of the breakdown of the physical components of the buildings and insufficient investment in maintenance. In Lima, this process of physical deterioration combined with social overcrowding is known as tugurización. ${ }^{(7)}$

\section{CURRENT DYNAMICS AND DEVELOPMENT TRENDS IN THE AREAS STUDIED: OWNERS, TENANTS AND OTHER ACTORS}

NOW, WE WILL review the development trends and current dynamics in the housing and real estate markets in the areas studied. These processes are found to differ significantly in the three cities and the political and legal situations, and the state of the market, also vary tremendously in each of these cities and areas.

\section{a. Lima}

The 1920s marked the beginning of a shift in the principal activities of Lima's formal real estate market from the historic centre to barrio Miraflores. The high percentage of slum dwellings in the centre and the complex situation with respect to legislation governing rental and ownership arrangements, combined with the conflicting positions of the dominant groups in relation to what to do with the centre areas of the city, led to stagnation in the formal real estate market in the city centre. Conversely, there was an inadvertent development of a new informal real estate market at the local level in the slum areas. It must be borne in mind that this type of market does not rely on formal channels of information such as periodicals or estate agents. It is a hidden market which is very active and complementary to the rental housing market, which is also informal. ${ }^{(8)}$

If we consider the characteristics of various types of building owners, we note that, in Lima, most absentee owners (those who do not live in the property) own entire buildings on large plots, for example, a solar, a quinta or callejón. There are three different types of large owner: institutional owners such as the Catholic Church, the University of San Marcos or the Public Aid Society of Lima; corporate owners such as real estate firms and banks; and individual or family owners. In addition, there are 
small owners who may own one or two dwelling units within the larger type of building. These small owners behave differently from the other groups of large landlords. Some large proprietors also adopt different attitudes vis-à-vis their property or tenants, i.e., the arrangement is not always purely for profit as tacit, long-established pre-capitalist social obligations are also present. Beginning in the 1940s and 1950s, transformations in the ownership structure occurred whereby the number of small owners increased, accompanied by a decreasing trend in the number of large owners. One possible explanation for this might be that some large property owners began to lose interest in the city centre location and in this form of rental property, and began to sell their property and capitalize in the formal market, in particular during the 1950s and 1960s, enabling them to find different uses for their assets. In addition, there was and still is an increasing desire among many tenants to become owners of the dwellings they occupy. Accordingly, within large properties, lots began to be sold with housing units to the tenants themselves or, less frequently, to other interested parties.

This shift toward the sub-division of larger units occurred primarily in solares and quintas and, to a lesser extent, in callejones and corralones owing to the unstable building condition of the latter structures.

How do owners, residents, tenants and other groups within society in Lima behave with respect to urbanization and the deterioration of buildings?

\section{i. Residents and Tenants}

To date, it has been considered a generally applicable phenomenon that the formation of "slums" follows an irreversible course of deterioration as none of the participants involved in the process has any interest in maintaining or improving the buildings in question. The research shows, however, that the real situation is quite different. In more than half the dwellings in the three areas studied, some type of improvement was detected. Most importantly, the residents themselves provided the main impetus for the improvements. This contradicts the assertion that no renovations will take place in run-down dwellings. While 75 per cent of the residents are aware that their dwellings require improvement, they show a tremendous capacity to make such improvements, which may be minor repairs, but which frequently also involve more permanent renovations such as the installation of hygienic services (toilet and showers) inside the dwelling, division of spaces through the construction of attics or altillos to provide more interior living space, and the installation or replacement of utilities. Most improvements have been made by the tenants themselves. The key factor in residents' decisions to make improvements has been the need to improve the habitability of their dwellings. The legal characteristics of tenancy (status as renters, for example), have not been important factors in the decision to invest. Most improvements are indicative that residents are willing to invest considerable economic resources despite the knowledge that the resources will not be recovered. Many efforts are made at the 
community level with the organization of supporting activities (parties, dances, raffles, etc.), to raise funds and to strengthen organizational ties which will be put to use in future project execution. This is an indication that residents do not view themselves merely as tenants - they also identify with their dwellings and with the neighbourhood, an attitude that does not exist among the owners.

Despite the formation of "slums" and overcrowding, residents do not view their situation as temporary. On the contrary, they view it as permanent. To remain in their homes and improve their living situation, they have developed certain attitudes and activities, defined as "urban space occupation strategies". The principal components of this "strategy" were found to be:

- considering their stay to be permanent;

- preventing the arrival or more people to live in the neighbourhood or property;

- maximizing the use of existing space; and

- expanding the living space to accommodate families and neighbours already living on the same site or in the same building and who, as it has been said, "have nowhere else to go". For these reasons, they rent or buy sub-divisions of the property with a view to living there or to receiving some type of income by using the property for economic purposes such as workshops, stores, etc. Sometimes collective contracts are signed to prevent outsiders from coming into the properties. A group of residents might use this technique to "appropriate" portions of a building or even entire solares or callejones, setting the stage for them to take collective decisions on the use of the space - for example, on whether improvements should be made, whether the property should be sublet or whether it should be used for some type of economic purpose.

\section{ii. Owners}

Small owners, who occupy their own units, are interested in the use value of their houses. They therefore invest in repairs and small improvements, in keeping with the economic resources at their disposal for that purpose. But those owners who do not live in the area and who act as real estate concerns or large individual owners whose main interest is to optimize the profit from their property and buildings do not make repairs or improvements to the facilities. Their aim is primarily to oust the tenants in order to put their property to more profitable use. In this process, real deterioration is allowed to take its course in the buildings. When a property has reached a critical state, the municipality may condemn it, thereby legalizing the eviction of the tenants under the pretext that the building must be demolished for reasons of safety. However, owners' failure to repair their properties is illegal as they are required by law to maintain rental housing in habitable condition.

\section{iii. Urban Administration}

The administration of metropolitan Lima to date has shown no interest in enforcing the ordinances provided by law that 
govern the maintenance of deteriorated buildings nor has it engaged in any activities to that end. This is not only a problem of bureaucratic inefficiency but also one of coordinating social, political and economic interests as components of a state and municipal policy. Urban investments by state and metropolitan governments during the 1980 s were much more heavily concentrated in the barriadas of Lima than in the centre. The inner-city areas received attention only in isolated cases, for example, repair work on sanitary services and washing facilities in old houses or help in repairing damage resulting from the collapse of a building. The reasons for this attitude may be due in part to the complicated legal situation governing central urban areas, which would require painstaking coordination efforts between owners and tenants. It would be very difficult to formulate common goals for both sides even where very general matters were concerned.

The municipality of Lima Cercado devoted somewhat more attention to the central part of the city during the 1990s than during the preceding decade. Projects were undertaken for two purposes. In one project, US\$ 2 million was allocated to improve buildings and urban areas of value to the historic heritage of the city. These funds were used to improve pavements, façades, balconies and lighting in the historic centre of the city. The main objective of the project was to promote tourism. The resources only produced an indirect benefit to the residents of the centre as the housing situation was not directly affected. The second project involved a small programme to improve sanitary facilities, in particular in Monserrate and Barrios Altos. To that end, just over US\$ 70,000 was invested during the period 1992-1993. The measures taken by the municipality to improve the "slums" are wholly insufficient. Other essential repair efforts, such as those involving the Ministry of Housing and national water and electricity companies, have had aims similar to those of the programme undertaken by the municipality.

\section{iv. Local and Community Organization}

In the past, there were few community organizations of any kind in the central neighbourhoods. Any such organizations that did exist were established for sports or religious pursuits. At present, there are many representative social organizations in the "slums" of the central urban area - primarily territorial associations such as neighbourhood boards concerned with the area or functional organizations aimed at addressing specific problems such as women's initiatives, for example, comites del vaso de leche or "glass of milk committees", so named for a municipal programme that began to distribute milk and food to children in 1981. Many such organizations were promoted during the Izquierda Unida or united left regime (1984-1986) in the municipality of metropolitan Lima. Since 1981, ordinances have been passed to acknowledge neighbourhood organizations in barriadas and in the inner-city.

Local associations and residents' organizing experiences constitute potential to be optimized if it were possible to implement improvement programmes for these inner-city neighbourhoods. 


\section{v. Housing Density and Overcrowding}

The housing situation in the three case study areas is characterized by high levels of overcrowding. One indicator of the degree of overcrowding is the number of square metres of constructed living area per resident. In the three areas studied, the average is 4.2 square metres per resident; less than ten square metres per resident is considered overcrowded. This assumption is based on official housing standards and the housing experience and expectations of the population in slum areas, barriadas and other residential zones.

In comparative terms, of the three areas studied, Mendosa Merino has the highest levels of overcrowding. To reduce this level, each dwelling would have to provide, as recommended by official standards, 10-12 square metres of living space per resident. With respect to housing type, the highest degrees of overcrowding are found in callejones ( 86 per cent) followed by the large sub-divided old court houses and the coralones (80 per cent). In addition to overcrowding, consideration must be given to the quality of the dwelling itself, its connections to drinking water, drains and sewers, electricity and the presence of sanitary facilities. The survey shows that, generally, such infrastructure facilities do exist in the areas. However, we find significant qualitative differences in the provision for each family dwelling. In callejones, corralones and, often, in solares, toilets and washing facilities are generally only available for communal use, an intolerable condition for most residents.

\section{vi. Income and Occupation}

The families in the three sectors are generally composed of residents with low incomes with between two-thirds and threequarters of the population earning less than US\$ 268 per month (families of five to six persons). This places them among Lima's poorest sectors. Approximately 50 per cent of the family incomes are below the official minimum wage (in 1992, the cost of a "basic family basket" was calculated at S/. 212.80, which is equivalent to US\$190).

\section{b. Río de Janeiro}

In Central District II RA of Río de Janeiro, in which Barrio Lapa is located, a wave of redevelopment projects over the last 100 years involving large-scale demolitions has led to the eviction of increasing numbers of residents from their homes. The concept of continuous progress, for society and the capitalist economy, dominated to such an extent that all planning regulations and measures that were adopted were expected to lead to the complete reconstruction of the central areas of the city. The traditional Portuguese city composed of small-scale, low buildings would be transformed into a modern city full of skyscrapers, along the lines of New York and Chicago. As these plans were not fully executed, the ruins of old buildings remain in many areas. Of the 3,000 cortiços existing in District II RA at the turn of the century, only 70 remained in 1991.

In recent years, a new phenomenon has occurred as a result 
of pressure from small local business people, professional associations and some tenants' organizations. In this connection, a large project for Avenida Norte-Sur was stopped. A new concept of the memoria urbana, or "urban remembrance", was discussed and positively valued with the aim of preserving both constructed areas and open spaces. On the edge of the central area, although outside District II RA, we find favelas with rental buildings, some of them up to four to five storeys high. This was the beginning of a "verticalization" of the favelas around the central area.

Two trends can be observed in the dynamics of the property market. The first consists of upgrading, possibly related to processes of restructuring in the direction of the "First World" and "global cities". The second trend consists of "downgrading", which may be related to the process of impoverishment and the decline of urban centres of the Third World. These two conflicting trends are combined in one very small area in the city of Río.

The building types with rental housing in Barrio Lapa range from new, high-quality "apartment-hotels" at the upper end of the scale to housing of the lowest standard, composed of the remaining cortiços, avenidas, casas de comodo and hospedades (generally for single men), which are generally very run down, at the other end. Between the two exists a moderate standard of housing for middle-income families - old apartment buildings and vilas dating back to the 1920s. As demand for rental housing in the inner-city far exceeds supply (this is true for all levels of income), a highly specialized form of rental housing has developed. The research found that this area also harbours a "hidden market" which consists of sub-letting independent rooms in different building types (including apartment buildings) by middle-class owners affected by the economic crisis. Such rooms are known as quartos or vagas; their supply and demand are clandestine.

The magnitude of the problem created by the lack of connection between urban renewal and housing policies is thus evident. The situation also reflects the extreme imbalance in income distribution at the national level as well as in Río. Average annual income in Brazil in the past decade has remained stable at approximately US\$ 1,850 although its distribution has undergone a sharp change: whilst ten years ago the poorest half of the population lived on an average annual income of US\$ 1,200, now they must survive on US\$ 900. This trend also affects the middle-class, whilst incomes in the upper-classes have increased considerably. In the areas adjacent to the centre, as well as in the favelas near the centre, building densities have increased and more floors are added. In the central district itself, the data and policies have been contradictory. While the population has decreased, its poorest sectors have been returning to the innercity. This is illustrated by the increase in the number of homeless, street peddlers and street children.

\section{c. Havana}

The situation in Havana is quite different. In the aftermath of 
the revolution in 1959, a number of important changes were made in the laws governing rental housing in the city. Immediately after the revolution, evictions were suspended and rents reduced. With the urban reform of 1960, the markets for housing, real estate and land were, to all intents and purposes, abolished. This was to put an end to speculation in land and real estate while housing lost its exchange value and its aspect as a commodity. In the most run-down housing types (cuarterias and ciudadelas) with communal water and toilet facilities, the rent relation was ceased and, in 1984, with the approval of the Ley General de la Vivienda (the new general housing law) rent-free use was given to the residents, with the intention of subsequently moving them to adequate housing. However, this did not stop the historic process of deterioration in such structures which had been in progress since before the revolution. With these measures, buildings were practically expropriated from their former owners and responsibility for maintenance was transferred to the state and the tenants.

Havana's ciudadelas and cuarterias house more than 60,000 families. In Barrio Atares, a total of 616 buildings are for housing purposes (single-family homes, apartment buildings, cuidadelas and cuarterías). Of these, 50 per cent are in a deplorable state of repair, while 11 per cent have been classified as irreparable. The Barrio Atares harbours 111 ciudadelas, representing only 18 per cent of the total buildings in the area. However, the 1,382 dwelling units within them account for 44.5 per cent of all existing dwellings in the area. This type of housing was and is in an extreme state of disrepair, with a high level of overcrowding. In order to increase useful living space, residents made internal sub-divisions by constructing entresols (46 per cent of the dwellings have barbacoas), expansions to the exterior or simply miscellaneous repair work. These activities by the residents were supported in part by state enterprises and micro-brigades. However the initiative came largely from the residents themselves.

Other participants and institutions who play an important role in the neighbourhoods are delegates from the peoples' council of Pilar Atares, from the municipal directorates of housing, architecture, urbanism, health, micro-brigades, etc., and organizations such as Committees for Defence of the Revolution (CDR) and the Federation of Cuban Women (FMC). An important actor with the capacity to mobilize people in some technological capacity is the Taller de Transformación Integral del Barrio, or the workshop for the coordinated transformation of the neighbourhood. Since the "special period" began, the activities of these institutions and organizations have been scaled down considerably. The scarcity of construction materials, means of transportation and energy, has led to stagnation in the construction industry. Ironically, the crisis has made it easier for the institutions to change their attitudes and abandon some sectoralist principles such as centralized solutions using inappropriate technologies. Thus began the search for alternatives to promote sustainable development.

The work of the residents - and women in particular - in the 
micro-brigades has served to reinforce their capacity to improve and change their dwellings. Existing housing units in Barrio Atares are generally well-equipped with water, sewer and electricity connections. More than 80 per cent of the dwellings are equipped with drinking water and 75 per cent have an inside toilet. Most of the dwellings were built during the 1920s and are in a better state of repair than in other areas where colonial buildings predominate. In total, some 60 per cent of the houses have failing roofs and damage from water seepage. Owing to the efforts of the residents themselves, many of the houses are undergoing perpetual transformation. In the ciudadelas, the most compelling factor is the need for more living space, more so than the need to repair structural damage. In the communal courtyards and access ways to the ground floor, extensions have been built, to be used as kitchens, bathrooms or pantries. These "appropriations" for private use generally cover a surface area of four to eight square metres. Sub-divisions and extensions are required when a family grows or when a new marriage or separation leads to the establishment of additional family units. In this case, new sanitary facilities will be created for more privacy. Most alterations take place inside the houses and courtyards. In addition, significant alterations can be seen from the street, on the building façades. In areas where entresols, or barbacoas, have been built, the alterations can be seen through the windows and, from time to time, are visible in the form of added balconies. Modern construction materials and a different aesthetic can be noted in the houses. In essence, a new image of the street is emerging with the creation of a "popular aesthetic" based on the actual needs of the residents and initiated by them. In most cases, the improvements are characterized by spontaneity and individuality and they are carried out without official control or technical assistance. The visual effect constitutes a departure from the original image of the neighbourhood, showing popular creativity and ingenuity as residents seek ways to solve their problems. These activities may be indicative of the great potential for active cooperation between the people, professionals and technical specialists, in addition to state support, in the formulation and implementation of neighbourhood renovation programmes.

\section{d. Conclusions}

Whilst at the end of the nineteenth century similar initial conditions existed in the cities and zones that were studied, it can be seen that development can lead to enormous differences in the present cities and barrios near the city centres. The current situation depends to a great extent on:

- the distribution of power among the three principal actors involved over a prolonged period of time;

- the role of the state in the formulation of laws and its role in large and small-scale planning initiatives;

- the role that the dominant actors in the real estate and land markets take; and 
- the potential role of the residents themselves and any freedom of manoeuvre that they are allowed.

\section{CONFLICTING INTERESTS IN CENTRAL RENTAL NEIGHBOURHOODS AND HOW THESE MIGHT BE RESOLVED}

THE RESULTS OF the study show increased overcrowding in both old and new dwellings in the areas near the centres of the cities studied. When a city is left open to real estate market forces or when (such as in Río de Janeiro) the state and market undertake long-term redevelopment involving large-scale demolition and eviction with a view to total urban reconstruction, we find a displacement of whole population groups and the creation of wastelands in the areas near the centre, with increased deterioration of the surviving buildings. We also note that planned intervention from the state and municipality is required. In this connection, there is a need for intervention at the legislative level (passage of laws) as well as at the local level (programming and coordinating the implementation).

A duality of interests and criteria exists where normative legislation is concerned. Whilst the residents view the problem of older run-down areas from the "right-to-housing" perspective, real estate investors regard it as a problem of underused or misused urban territory and see the areas as potentially available for development with capital investment and for capital gain.

The problem of conflicting interests and objectives should be resolved in the political arena through laws and state contributions, possibly through compromise agreements. At the local level, programme aspects - design, planning and implementation of urban renewal strategies and projects - should be addressed through concerted work and cooperation between the various actors involved in civil society, including the residents and their organizations. The aim should be a strategy of urban renewal in the medium and long term that takes due account of social objectives, is mindful and respectful of the history of the city while being adaptable to the specific characteristics of each location, the residents and their experiences. 